\title{
I-Cell Disease: Biochemical Studies
}

\author{
Jules G. Leroy, Mae Wan Ho, Monica C. MacBrinn, Klaus Zielke, Jack Jacob, and John S. O'Brien ${ }^{132}$ \\ Department of Genetics, Artwerp State University, Artwerp, Belgium, and Department of Neurosciences, University of \\ California, San Diego, School of Medicine, La Jolla, California, USA
}

\begin{abstract}
Extract
Six patients with I-cell disease (ICD) are studied. Multiple acid hydrolase deficiencies are demonstrated in cultured skin fibroblasts. These include $\beta$-galactosidase $(2 \%$ of normal), $\beta$-glucosaminidase ( $8 \%$ of normal), $\beta$-glucuronidase $(7 \%$ of normal), $\alpha$-galactosidase ( $10 \%$ of normal), and arylsulfatase A ( $5 \%$ of normal). Acid hydrolases found not to be deficient include $\beta$-glucosidase and acid phosphatase.

In brain and visceral organs, only $\beta$-galactosidase is deficient $(27 \%$ of normal in brain; $11 \%$ of normal in liver).

A nonspecific accumulation of lipids of all classes occurs in skin fibroblasts (2-3 times normal), but not in brain or visceral organs.

No accumulation of acid mucopolysaccharides is demonstrated in skin fibroblasts or liver.
\end{abstract}

\section{Speculation}

I-cell disease may represent a unique opportunity for the study of control of intracellular levels of lysosomal enzymes.

\section{Introduction}

"I-cell" or "inclusion cell" disease (ICD) is a hereditary disorder of childhood, named from the phase contrast appearance of cultured skin fibroblasts from affected patients. The cytoplasm of cultured fibroblasts is filled with granular inclusions [6]. Recently I-cell disease has also been called mucolipidosis II [16]. The disease presents clinically [7] as a slowly progressive disorder with severe growth retardation, skeletal dysplasia, psychomotor retardation, gingival hyperplasia, coarsening of facial features similar to those seen in the Hurler syndrome (MPS type I), and fatal outcome within the lst decade. The corneas of ICD patients are only occasionally cloudy, hepatosplenomegaly is minimal or absent, and urinary excretion of acid mucopolysaccharides (AMPS) is normal. Pedigree analyses indicate that ICD is transmitted as an autosomal recessive trait [7].
The nature of the cytoplasmic inclusions in cultured skin fibroblasts is unknown. Ultrastructural studies [5, 20] suggest they are storage cytosomes, possibly derived from lysosomes. In this report we present the results of chemical analyses of the storage material in I-cells as well as the activity of lysosomal hydrolases in these cells. Postmortem analyses of frozen tissues from two patients with I-cell disease are also presented.

\section{Materials and Methods}

\section{Subjects}

Patients $L G, J G, O W, S S, U S$, and $S V$ have been described clinically by Leroy et al. [7]. Patients $B E$ and $J B$ have been studied by Tondeur et al. [20] and by Eggermont et al. [3], respectively. Patient $C M$ is currently being followed at the Johns Hopkins Hospital, Baltimore, Maryland. 


\section{Cultures of Skin Fibroblasts}

Fibroblast cultures were obtained from skin biopsies and propagated in media $\mathrm{F}-10$ containing $15 \%$ fetal calf serum according to methods published previously [6]. For chemical analyses as well as for enzyme studies, cultures of control and patient cell strains were started simultaneously, using in each instance a similar number of cells. All cultures were harvested between 5 and 7 days after they had reached confluency, at which time the cell number had become five times that of the inoculum.

\section{Organs}

Specimens of liver, brain, kidney, and spleen, obtained at autopsy, were frozen and kept at $-20^{\circ}$ until analysis.

\section{Enzyme Assays}

$N$-Acetyl- $\beta$-D-glucosaminidase, $\beta$-D-galactosidase, $\beta$-Dglucosidase, $\beta$-D-glucuronidase, $\beta$-D-xylosidase, $\alpha$-D-galactosidase, and $\alpha$-D-mannosidase were assayed fluorometrically by measuring 4-methylumbelliferone released from the appropriate glycosidic derivatives [24] (Table I). The concentrations of homogenates used were $1: 50$ $(\mathrm{w} / \mathrm{v})$ for liver, skin biopsies, spleen, and kidney; $1: 20$ $(\mathrm{w} / \mathrm{v})$ for brain; and $1: 10(\mathrm{v} / \mathrm{v})$ for cultured skin fibroblasts.

The reaction was stopped with $1 \mathrm{ml} 0.085 \mathrm{M}$ glycine carbonate buffer, $\mathrm{pH} 10$, and fluorescence was measured with a Turner fluorometer at an excitation wavelength of $365 \mathrm{~m}_{\mu}$ and an emission wavelength of 450 $\mathrm{m}_{\mu}$. 4-Methylumbelliferone dissolved in the same glycine-carbonate buffer was used as the standard.

Arylsulfatase $A$ activity was assayed according to the method of Percy and Brady [14], using p-nitrocatecholsulfate as substrate.

Acid phosphatase was assayed spectrophotometrically [11] with $p$-nitrophenylphosphate [25] as substrate.

\section{Lipid Analyses}

Frozen brain and liver obtained at autopsy were available from patients $J G$ and $S V$. Control tissues were obtained from patients ranging in age from 13 days to 55 years who expired from noncerebral causes. Lipid analysis was carried out on cultured fibroblasts from patients $L G$ and $J G$, both their parents, and five control subjects. Lipids were extracted by treating the samples with chloroform-methanol, 2:1, in a nitrogen atmosphere as previously described [12]. After evaporation of the solvent, the amount of lipid present was determined by weighing the lipid extract and the nonlipid residue. Two-dimensional thin layer chromatography [13] was carried out using plates coated with Silica Gel G to compare visually the total lipid composition of the patients' tissues or fibroblasts with that of control subjects. Thin layer plates were stained with iodine vapor or charred with potassium dichromatesulfuric acid to visualize lipids. Galactolipids were also stained with orcinol-sulfuric acid, and gangliosides were stained with resorcinol. Lipids in the patients' tissues were quantified by the method of Suzuki [17] using silica gel-coated plates; phosphorus, hexose, and cholesterol contents were determined after each lipid was scraped from the chromatoplates. Total ganglioside-sialic acid in the patients' tissues was determined by the resorcinol method [19].

\section{Analyses of Acid Mucopolysaccharides}

Isolation of acid mucopolysaccharides [18] was carried out by extracting specimens $(250 \mathrm{mg}$ wet wt) with 20 volumes chloroform-methanol, 2:1. After the solvent-extracted residue was dried overnight in a desiccator, it was homogenized in $2 \mathrm{ml} 0.1 \mathrm{M}$ sodium phosphate buffer ( $\mathrm{pH}$ 7.5) and digested with Pronase [26] at a final concentration of $0.25 \mathrm{mg} / \mathrm{ml}$ for $24 \mathrm{hr}$ at $50^{\circ}$. The undigested residue was removed by centrifugation. Three volumes of ethanol saturated with $\mathrm{NaCl}$ were added to the supernate, and crude mucopolysac-

Table 1 . Conditions of enzyme assays

\begin{tabular}{|c|c|c|c|c|c|c|c|c|}
\hline \multirow[b]{2}{*}{ Enzyme } & \multicolumn{3}{|c|}{ Buffer-substrate } & \multirow{2}{*}{$\begin{array}{l}\text { Substrate } \\
\text { conc, } \\
\text { mM }\end{array}$} & \multirow[b]{2}{*}{ Additions } & \multirow{2}{*}{$\begin{array}{l}\text { Homo- } \\
\text { genate, } \\
\mu \text { liters }\end{array}$} & \multirow{2}{*}{$\begin{array}{l}\text { Buffer- } \\
\text { substrate, } \\
\mu \text { liters }\end{array}$} & \multirow{2}{*}{$\begin{array}{l}\text { Incubation, } \\
\text { min }\end{array}$} \\
\hline & Composition & Strength, & $\mathrm{pH}$ & & & & & \\
\hline$\beta$-Galactosidase & Citrate-phosphate & 0.022 & 4.35 & 0.5 & $0.1 \mathrm{~m} \mathrm{NaCl}$ & 10 & 50 & 15,30 \\
\hline F-Glucosaminidase & Citrate-phosphate & 0.022 & 4.40 & 1.0 & $\begin{array}{c}0.1 \% \text { human } \\
\text { albumin }\end{array}$ & $\overline{5}$ & 100 & 15,30 \\
\hline$\beta$-Glucuronidase & Citrate-phosphate & 0.020 & 4.05 & 1.0 & & 10 & 50 & 15,30 \\
\hline$\beta-$ Glucosidase & Citrate-phosphate & 0.020 & 4.05 & 1.0 & & 10 & 50 & 30,60 \\
\hline$\alpha$-Galactosidase & Citrate-phosphate & 0.022 & 4.50 & 10.0 & & 10 & 50 & 15,30 \\
\hline$\alpha$-Mannosidase & Citrate-phosphate & 0.025 & 5.05 & 1.0 & & 10 & 50 & 15,30 \\
\hline
\end{tabular}


charides were precipitated at $4^{\circ}$ for $12 \mathrm{hr}$. The precipitate was dissolved in $2 \mathrm{ml} 0.5 \mathrm{M}$ acetic acid in $5 \%$ sodium acetate and reprecipitated with 4 volumes ethanol. The precipitate was dissolved in $2 \mathrm{ml} 0.01 \mathrm{M}$ sodium phosphate buffer (pH 7.0) with $0.01 \mathrm{M} \mathrm{NaCl}$ and incubated with $5 \mu 1 \alpha$-amylase [27] for $2 \mathrm{hr}$ at $37^{\circ}$. Crude mucopolysaccharides were then precipitated with 4 volumes ethanol and washed with $80 \%$ ethanol.

Table II. Acid hydrolase activities ${ }^{1}$

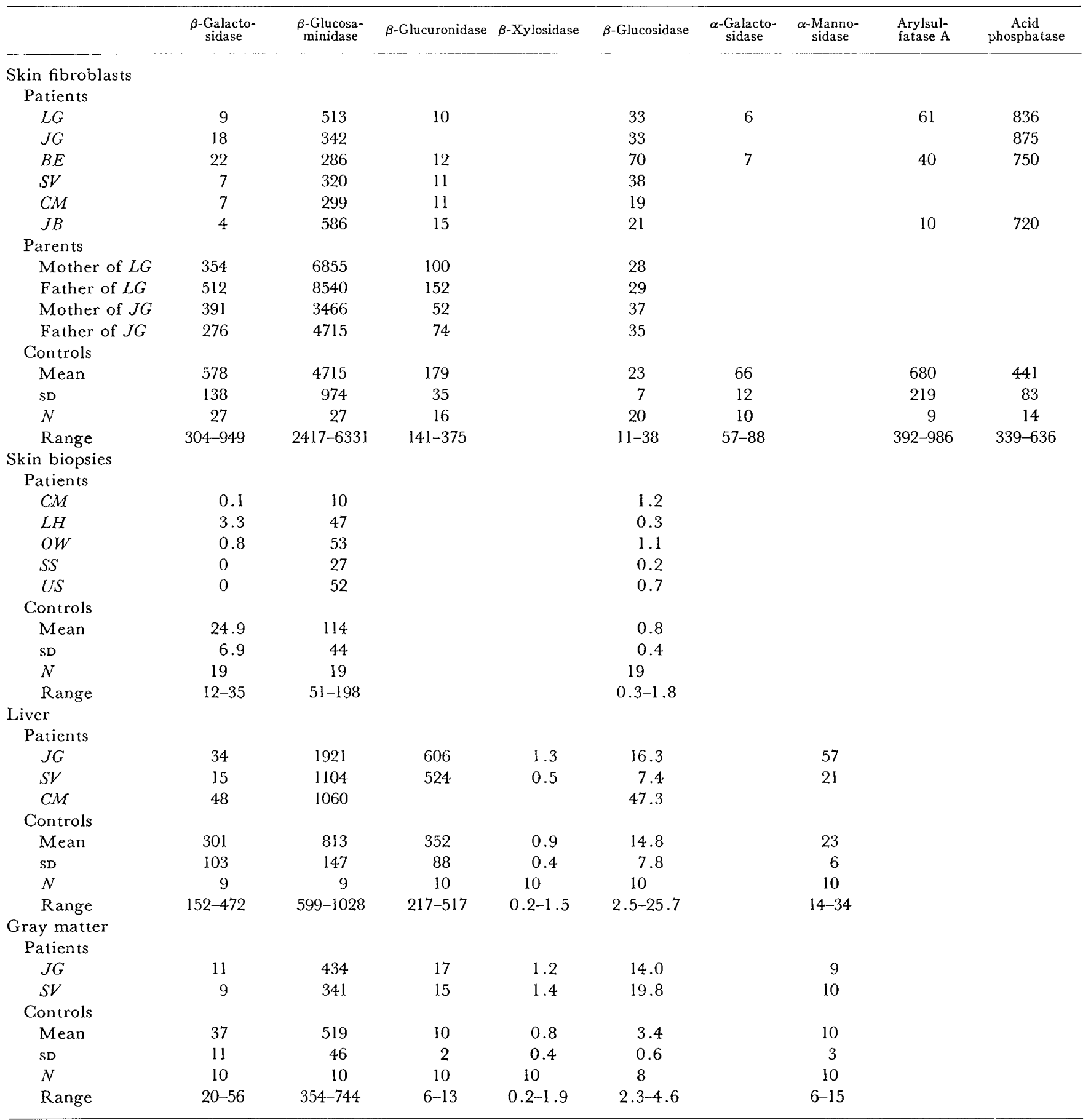

${ }^{1}$ Enzyme activity is expressed as mumoles substrate cleaved per mg protein per hr at $37^{\circ}$. 
The dried powder was redissolved in distilled water for determination of uronic acid and hexosamine.

Uronic acid was determined according to the method of Bitter and Muir [1]. Hexosamine was determined according to the method of Boas [2].

\section{Results}

\section{Enzyme Assays}

Skin fibroblasts from patients with ICD were markedly deficient in $\beta$-galactosidase, $\beta$-glucosaminidase, $\beta$-glucuronidase, $\alpha$-galactosidase, and arylsulfatase $A$ activities (Table II). Normal activities were found for $\beta$-glucosidase and acid phosphatase. Skin biopsies from ICD patients were also deficient in $\beta$-galactosidase and $\beta$-glucosaminidase activities as compared with samples from control subjects (Table II).

In the liver and cerebral grey matter from patients with ICD, the activities of all enzymes tested fell within the normal range with the exception of $\beta$-galactosidase, which was reduced to about $10 \%$ of the control value in the liver and to $25 \%$ of the control value in gray matter.

Reduced levels of $\beta$-galactosidase were also found in spleen and kidney. The reduction of $\beta$-galactosidase activity was demonstrated using both $p$-nitrophenyland 4-methylumbelliferyl-galactosides as substrates.

The enzyme deficiencies in skin fibroblasts and the $\beta$-galactosidase deficiency in other tissues were not due to the presence of soluble endogenous inhibitors. This was demonstrated by mixing homogenates of fibroblasts or frozen tissues from control subjects with those from each patient. The mixtures were assayed for enzyme specific activity; assays of all enzymes which were reduced in activity gave the expected intermediate reduction of specific activity in the mixed homogenates.

\section{Lipid Analysis}

The lipid contents of brain, liver, and spleen from patients $J G$ and $S V$ were within normal limits. Twodimensional thin layer chromatography of lipid extracts from each organ demonstrated no apparent alteration in the proportions of triglycerides, cholesterol, cholesterol esters, free fatty acids, phosphatidyl ethanolamine, phosphatidyl serine, lecithin, sphingomyelin, phosphatidyl inositol, cardiolipin, gangliosides, or other glycolipids. Cerebral ganglioside patterns in both patients appeared within normal limits.

The lipid content of I-cell fibroblasts was increased approximately three times those of controls (Table III).
Nonetheless, thin layer chromatography of fibroblast lipid extracts and fractionation of lipids by diethylaminoethyl cellulose chromatography [12] revealed no change in relative percentage of any single lipid. Uniform increases of all fibroblast lipids was apparent, including cholesterol, glycerophosphatides, and glycosphingolipids. Lipid analyses of fibroblasts from parents of two patients gave lipid contents which were higher than the mean of control values; the values fell in the high normal range (Table III).

\section{Mucopolysaccharide Analyses}

No difference was found between the contents of mucopolysaccharides in liver of two ICD patients and in that of control subjects when mucopolysaccharides were quantified on the basis of their uronic acid and hexosamine contents. The content of total mucopolysaccharides in I-cell fibroblasts was also not significantly different from that of normal fibroblasts (Table IV).

\section{Discussion}

We know of no disorder, other than I-cell disease, which involves deficiencies of multiple lysosomal hydrolases in cultured skin fibroblasts. This is useful in the differential diagnosis of ICD from clinically similar disorders such as Hurler's syndrome (MPS I), fucosidosis, and generalized gangliosidosis $\left(\mathrm{GM}_{1}\right.$-gangliosiclosis type I) [7]. In cultured skin fibroblasts, no deficiency of any of the lysosomal hydrolases assayed occurs in Hurler's syndrome [4], only $\alpha$-fucosidase is deficient in fucosidosis $[21,23]$, and only $\beta$-galactosidase is cleficient in generalized gangliosidosis [15].

Deficiencies of multiple lysosomal hydrolases were also demonstrated in the fibroblasts of the patient studied by Lightbody et al. [9], who have confirmed our preliminary results [8].

It is of interest to note that in four parental strains of fibroblasts, the activity of all hydrolases is not inter-

Table III. Lipid content of I-cell fibroblasts

\begin{tabular}{lc}
\hline \multicolumn{1}{c}{ Subject } & Lipid content, \% dry wt \\
\hline Patient $L G$ & 31 \\
$L G$ 's mo.her & 16 \\
$L G$ 's father & 17 \\
Patient $J G$ & 26 \\
$J G$ 's mother & 18 \\
$J G$ 's father & 17 \\
Controls $(5)$ & 11 \\
Range & $(7-17)$ \\
\hline
\end{tabular}


Table IV. Acid mucopolysaccharide content

\begin{tabular}{cc}
\hline & AMPS, $\mu \mathrm{g} / \mathrm{mg}$ protein 1 \\
\hline Skin fibroblasts & \\
Patients & 21.9 \\
$J G$ & 15.4 \\
$S V$ & \\
Parents & 23.5 \\
Mother of $J G$ & 33.4 \\
Father of $J G$ & 17.6 \\
Mother of $S V$ & \\
Control subjects & 12.3 \\
no. 45 & 21.2 \\
$n o .51$ & \\
Liver & \\
Patients & 42.5 \\
JG & 32.9 \\
SV & \\
Control subjects & 32.6 \\
A68-2 & 19.1 \\
A68-3 & 36.3 \\
A68-4 & 62.7 \\
A68-5 & 30.2 \\
A68-6 & 37.4 \\
A68-8 & \\
\hline
\end{tabular}

1 Chondroitin sulfate was used as standard in an assay for uronic acid. AMPS: acid mucopolysaccharides.

mediate between mutant and control strains, but normal (Table II).

In our patients with ICD the only lysosomal hydrolase found to be deficient in postmortem tissues is $\beta$ galactosidase. Lucksinger et al. [10] also reported this to be the only lysosomal hydrolase enzyme deficient in repeated liver biopsies of their patient with I-cell disease. However, in five patients studied by Van Hoof and Hers [21], two had a deficiency of $\beta$-galactosidase in liver and three did not. This inconsistency could be due to heterogeneity among patients with I-cell disease or variability of the $\beta$-galactosidase deficiency.

A nonspecific accumulation of lipids occurs in cultured skin fibroblasts from patients with ICD. The relationship of the lipid accumulation to the fundamental defect is not clear. Examination of postmortem tissues from patients with I-cell disease demonstrated no significant accumulation of total lipids or of any specific lipid. Moreover, no single lipid was found to accumulate within I-cell fibroblasts, indicating that Icell disease is not a lipidosis in the classical sense.

The acid mucopolysaccharide content of cultured fibroblasts and of liver from patients with I-cell disease is also not elevated, demonstrating that I-cell disease does not involve hepatic mucopolysaccharide storage. For these reasons it appears to be inappropriate to designate I-cell disease as a "mucolipidosis" [16], since neither mucopolysaccharides nor lipids were found to accumulate in the tissues we had available for study.

The cause of multiple enzyme deficiencies in cultured skin fibroblasts in I-cell disease is unknown. This multiple enzyme deficiency appears to be present in vivo, at least in fresh skin (although not in other organs).

Wiesmann et al. [22] have reported excessive leakage of some acid hydrolases into the culture media in skin fibroblasts from an I-cell patient. Preliminary studies in our laboratory are in accordance with this finding. Further exploration of the cellular and molecular biology of $\mathrm{I}$-cell disease is indicated in order to achieve understanding of the fundamental defect in this remarkable disease.

\section{Summary}

Multiple acid hydrolase deficiencies were demonstrated in cultured skin fibroblasts from patients with I-cell disease. These deficiencies may be due to excessive leakage of enzymes from the cells.

In brain and visceral organs, only $\beta$-galactosidase was deficient.

A nonspecific accumulation of all classes of lipids occurred in skin fibroblasts, but not in brain or visceral organs.

No accumulation of acid mucopolysaccharides was found in skin fibroblasts or in liver.

I-cell disease does not present as a classical lipid or mucopolysaccharide storage disorder. The characteristic multiple enzyme deficiencies in skin fibroblasts serve to distinguish it from clinically similar disorders.

\section{References and Notes}

1. Bitter, T., AND Murr, H. M.: A modified uronic acid carbazole reaction. Anal. Biochem., 4: 330 (1962).

2. BOAs, N. F.: Method for the determination of hexosamines in tissues. J. Biol. Chem., 204: 553 (1953).

3. Eggermont, E.: Connatale vorm van gargoylisme. In: Abstracts of Annual Meeting of Belgian Society of Pediatrics, Louvain, Belgium, p. 10 (1970).

4. Fruharty, A. L., et al.: Acid glycosidases in mucopolysaccharidoses fibroblasts. Biochem. Med., 4: 110 (1970).

5. Hanai, J., Leroy, J. G., and O'Brien, J. S.: Ultrastructure of cultured fibroblasts in I-cell disease. Amer. J. Dis. Child., 122: 34 (1971).

6. Leroy, J. G., and Df.Mars, R. I.: Mutant enzymatic and cytological phenotypes in cultured human fibroblasts. Science, 157: 804 (1967).

7. Leroy, J. G., et al.: I-cell disease, a clinical picture. J. Pediat., 79: $360(1971)$. 
8. Leroy, J. G., et al.: I-cell disease, entity detected in cell culture. Bull. Eur. Soc. Hum. Genet., 3: 40 (1969).

9. Lightbody, J., et al.: I-cell discase: multiple lysosomal enzyme defect. Lancet, $i$ : 451 (1971).

10. Lucksinger, V., et al.: I-cell disease. New Engl. J. Med., 282: $1374(1970)$.

11. MacBrinn, M. C., et al.: $\beta$-Galactosidase deficiency in the Hurler syndrome. New Engl. J. Med., 281: 338 (1969).

12. O'Brien, J. S., and Sampson, E. L.: Lipid composition of the normal human brain: gray matter, white matter and myelin. J. Lipid Res., 6: 537 (1965).

13. Parsons, J. G., and Patron, S.: Two dimensional thin-layer chromatography of polar lipids from milk and mammary tissue. J. Lipid Res., 8: 696 (1967).

14. Percy, A. K., and Brady, R. O.: Metachromatic leukodystrophy: diagnosis with samples of venous blood. Science, 161: 594 (1968).

15. SLOAN, H. R., et al.: $\beta$-Galactosidase in tissue culture derived from human skin and bone marrow: enzyme defect in $\mathrm{GM}_{\mathbf{1}}$ gangliosidosis. Pediat. Res., 3 : 532 (1969).

16. Spranger, J. W., and Wiedemann, H. R.: The genetic mucolipidoses. Humangenetik, 9: 113 (1970).

17. SUzUkI, K.: A simple and accurate micromethod for quantitative determination of ganglioside patterns. Life Sci., 3: 1227 (1964).

18. Suzuki, K., Suzuki, K., and Kamoshita, S.: Chemical pathology of $\mathrm{GM}_{1}$-gangliosidosis (generalized gangliosidosis). J. Neuropathol. Exp. Neurol., 28: 25 (1969).

19. Svennerholm, L.: Quantitative estimation of sialic acids; II. A colorimetric resorcinol-hydrochloric acid method. Biochim. Biophys. Acta, 24: 604 (1957).

20. Tondeur, M., et al.: Clinical, biochemical and ultrastructural studies in a case of chondrodystrophy presenting the I-cell phenotype in tissue culture. J. Pediat. 79: 366 (197l).

21. Van Hoof, F., AND Hers, H. G.: The abnormalities of lysosomal enzymes in mucopolysaccharidoses. Eur. J. Biochem., 7: 34 (1968).

22. WIESMANN, U. N., et al.: Multiple lysosomal enzyme deficiency due to enzyme leakage. New Engl. J. Med., 284: 109 (1971).

23. Zielke, K., Okada, S., And O'Brien, J. S.: Fucosidosis: diagnosis by serum assay of $\alpha$-L-fucosidase. J. Lab. Clin. Med., 79: I64 (1972).

24. Koch Light, England.

25. Sigma Chemical Company, St. Louis, Mo.

26. B grade, Calbiochem, Los Angeles, Calif.

27. Dog pancreas, Signa Chemical Company, St. Louis, Mo.

28. Informed consent for publication of clinical data on the subjects reported herein has been granted by parties involved.

29. We thank Drs. A. C. Crocker, J. M. Opitz, J. Spranger, M. Feingold, H. Loeb, E. Eggermont, and V. McKusick for referring patients to us. Dr. R. I. DeMars has kindly supplied us with some of the skin fibroblast strains used in these studies.

30. Excellent technical assistance was given by Mrs. A. De Becker, L. Tennant, L. Veath, and Miss M. Roemans.

31. This work was supported by the Fonds voor Geneeskundig wetenschappelijk onderzoek, Brussels, Belgium and by grants from the National Foundation, the National Genetics Foundation, the National Cystic Fibrosis Foundation, the National Institutes of Health Grant no. NB08682, and the National Institutes of Health Program Grant no. GM 17702-0I.

32. Requests for reprints should be addressed to: John S. O'Brien, M.D., Department of Neurosciences, University of California, San Diego, La Jolla, Calif. 92037 (USA).

33. Accepted for publication May 23, 1972. 